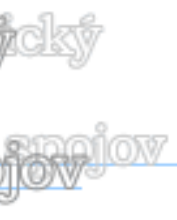

\title{
ANALÝZA FORIEM INTERNETOVEJ REKLAMY - BANNERY
}

\author{
Radovan Madleňák*
}

\section{Úvod}

Internet je $\mathrm{v}$ súčasnosti najpopulárnejším reklamným elektronickým médiom. Reklamné prúžky, alebo tzv. bannery sú pravdepodobne najčastejšie využívanou formou reklamy na Internete.

Prúžková reklama vznikla v USA, ked’ v roku 25. októbra 1994 na serveri časopisu HotWired, začala ako prvá inzerovat' americká telekomunikačná spoločnost' AT\&T. Rozmer prvého banneru bol zvolený "jeden krát sedem palcov", čo na vtedy prevládajúcich 14 palcových monitoroch predstavovalo prúžok vedený prakticky celou šírkou monitora.

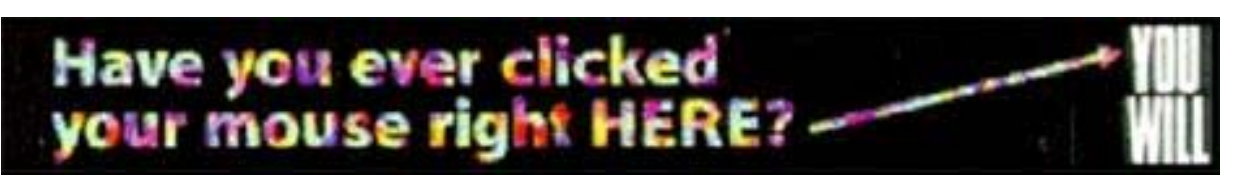

Obrázok 1 Prvý reklamný banner

Princíp bannerovej reklamy spočíva $\mathrm{v}$ tom, že sa do HTML stránky umiestni podlhovastý inzertný obrázok. Ak návštevníka stránky obrázok zaujme a klikne naň, prenesie sa na stránku klienta, ktorá obsahuje podrobné informácie o inzerovanom tovare, službe, firme, spoločnosti apod.

Banner predstavuje základný reklamný komunikačný prvok na internete. Počas existencie internetovej reklamy prešiel dramatickým vývojom, čo priamo súvisí s rozvojom technológií (flash, streamované video, shockwave, java...). Vd'aka tomu dnes popri tradičných formátoch v pomerne hojnej miere evidujeme aj menej tradičné formy.

Napriek týmto skutočnostiam však nad'alej prevláda obdížnikový tvar bannerovej reklamy, čo často navodzuje dojem, že banner má pomerne vel'a spoločného s tradičným inzerátom, resp. billboardom. Banner, rovnako ako billboard, či inzerát $\mathrm{v}$ časopise má svoj plošný obsah. Najčastejšie sa vel'kost' bannera vyjadruje v px (pixel - prestavuje plošnú i dížkovú mieru zároveň), alebo v kB. Tu sa vel'mi výrazne prejavuje špecifikum bannera a jeho naviazanost' na informačné technológie.

Zatial', čo sa vo fyzickom svete obchoduje s plochou, a teda hlavným kritériom je obsah, na internete je ovel'a dôležitejší objem dát. Nie je totiž problémom vytvorit' teoreticky až neobmedzené množstvo reklamných plôch. Limitom v prostredí internetu je rýchlost', preto čím väčší objem dát je nutné preniest', aby sa banner zobrazil, tým sa zobrazí neskôr, a tým menšia je pravdepodobnost', že ho potenciálny klient, či len „obyčajný“ návštevník, uvidí.

\footnotetext{
* Ing. Radovan Madleňák, PhD., Žilinská univerzita v Žiline, Fakulta Prevádzky a ekonomiky dopravy a spojov, Katedra spojov, Univerzitná 1, 01026 Žilina, tel. č.: 041/513 3124, fax: 041/ 5655 615, e-mail: Radovan.Madlenak@fpedas.utc.sk
} 
Platí teda vzt'ah: Čím je banner objemovo menší, tým je väčšia pravdepodobnost', že sa zobrazina $W W W$ stránke.

\section{Druhy bannerovej reklamy}

Aj ked' jedným z hlavných kritérí je objem dát, odborná i laická internetová verejnost' už od počiatkov existencie internetovej reklamy silne vnímala potrebu štandardizácie rozmerov reklamných plôch. Organizácia Interactive Advertising Buriau (IAB) preto publikovala smernice, $\mathrm{v}$ ktorých definovala plošné štandardy. Aj ked' sama IAB stavia dodržiavanie uvedených formátov na dobrovol'nosti, resp. odporúčaní, väčšina odborníkov z oblasti internetového marketingu ich považuje za jediné prípustné.

468x60 plný baner (full banner)

392x72 plný baner s vertikálnou navigačnou lištou
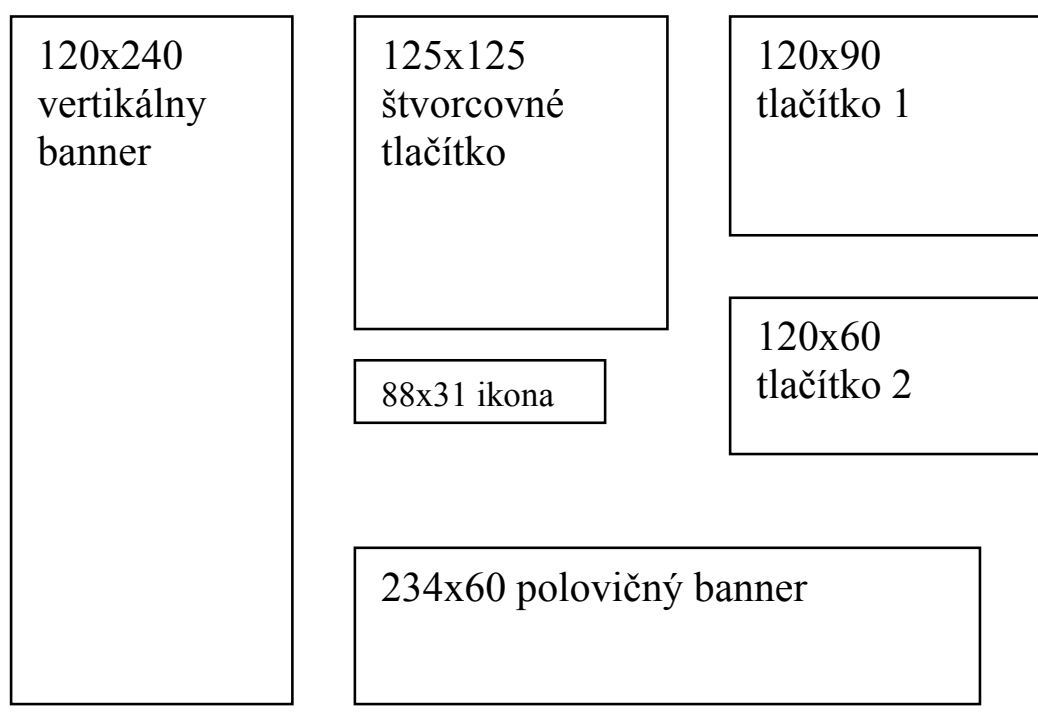

Obrázok 2 Prehl’ad základných druhov bannerovej reklamy podl’a IAB

Na základe odporúčaní IAB sa vyvinuli okrem základných druhov bannerovej reklamy aj d’alšie odvodené formy, ktoré sú spoločne uvedené v nasledovnom prehl'ade:

\section{A. Full banner $(468 \times 60 \mathrm{px})$}

Je základným formátom, obdobou formátu A4 vo svete polygrafie. Možno si všimnút', že od neho sa, vo väčšej, či menšej miere odvíja vel'kost' ostatných formátov (half banner šírka + výška, button 1 - výška...). Aj v súčasnosti je najčastejšie používaným formátom na internete. Ak nejaká stránka obsahuje reklamu, možno takmer s určitost'ou povedat', že ide o tento formát. Poskytovatelia freehostingov mnohých prípadoch žiadajú od používatel'ov ich služieb umiestnenie full bannera na ich stránku. Ked’že ide o najčastejšie používaný formát, práve full banner je predmetom výmenných reklamných systémov. 


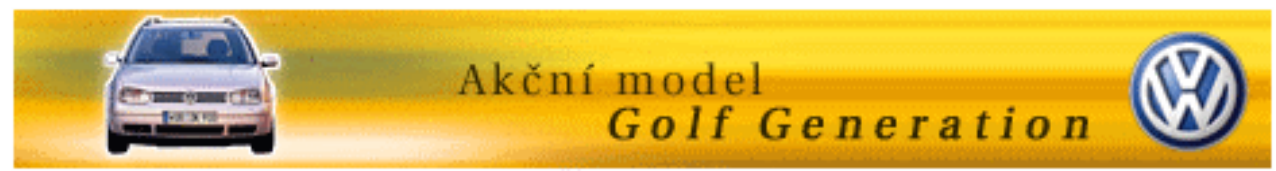

Obrázok 3 Full banner

\section{B. Button $1(120 \times 60 \mathrm{px})$}

Oblúbený formát situovaný často bud' vedl'a full bannera alebo v stĺpci, pod/nad navigačnými prvkami.
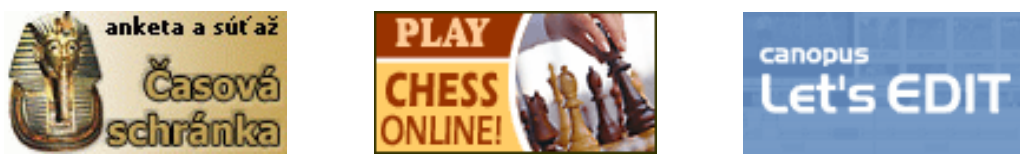

Obrázok 4 Button 1

\section{Button $2(120 \times 90 \mathrm{px})$}

Menej často používaný, než button 1. Podobne ako button 1, aj Button 2 býva najčastejšie situovaný nad/pod navigačnými prvkami webu, na okrajoch stránky.
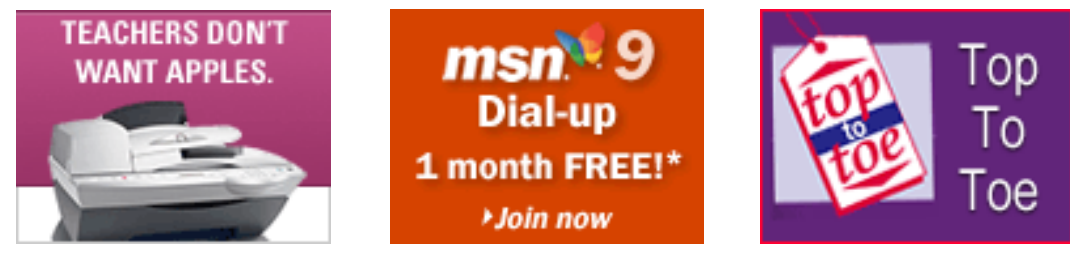

Obrázok 5 Button 2

\section{Sqaure - "štvorec" $(125 \times 125 \mathrm{px})$}

Oblúbený formát. Využívaný predovšetkým na rôznych portáloch a spravodajských severoch s trojstlípcovým layoutom (Interval.cz, Zoznam.sk, Pobox.sk, Lupa.cz, Atlas.sk/cz).
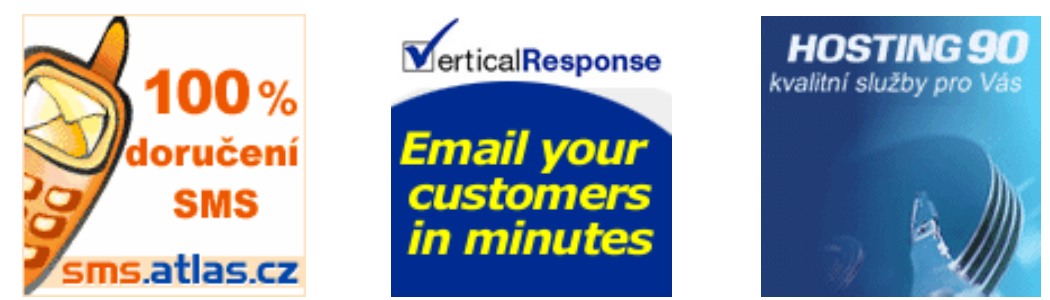

Obrázok 6 Square

\section{E. Vertical banner $(120 \times 240$ px $)$}

Prvý pokus definovat' reklamnú plochu s vertikálnou orientáciou. Využitie nachádza predovšetkým v trojstĺpcovej sadzbe, na portáloch atd'. Výhody sú zrejmé najmä pri čítaní zrak užívatel'a banner pri sledovaní obsahu nemíňa. Vd’aka vertikálnej orientácii je reklama pomerne dlho v zornom poli. Tieto dôvody viedli $\mathrm{k}$ neskoršiemu zavedeniu skyscraper a wide scyscrapers. 

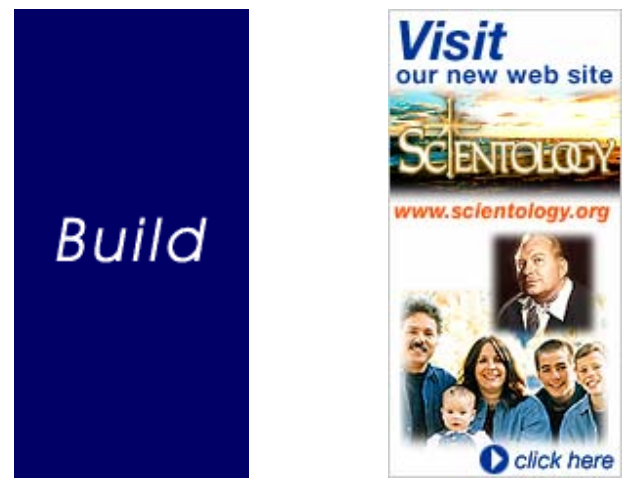

Obrázok 7 Vertical banner

\section{F. Splash}

Splash je banner, ktorý sa na určitý čas vysunie zo svojej pozície do väčších rozmerov a následne sa opät' zmenší spät' na štandardnú vel'kost' t.j. 468 x 60 pixelov. Umožňuje tak zobrazenie väčšieho množstva informácií a tým viac upúta.

\section{G. Skyscraper a wide-skyscraper}

Predstavujú mimoriadne zaujímavé formáty s vel'kou perspektívou vývoja. Vd'aka vertikálnej orientácii sú návštevníkovi neustále na očiach a tým sa vel'mi dobre uplatňujú na weboch s množstvom písaného textu - magazíny, spravodajské servery, e-shopy atd'. Tak, ako užívatel' roluje stránku stále nižšie, získava paralelne aj reklamné informácie. Čo sa týka technológie tvorby týchto bannerov, je viac než žiaduce využívat' technológiu Flash firmy Macromedia (Gold, 2002). Cena skyscrapera je oproti klasickému full banneru pomerne vysoká.

\section{H. Microbutton $(88 \times 31 \mathrm{px})$}

Vel'mi špecifická reklamná plocha. Vd’aka svojej vel'kosti býva vd’ačným prvkom vzájomnej propagácie serverov. V tejto súvislosti je zaujímavé sledovat' kol'ko informácií sa dá vtesnat' na takú malú plochu. Tá pre mnohých grafikov zjavne nepredstavuje väčší problém, takže tieto drobné grafiky môžu nezriedka po grafickej i obsahovej stránke smelo konkurovat' ovel'a väčším formátom.
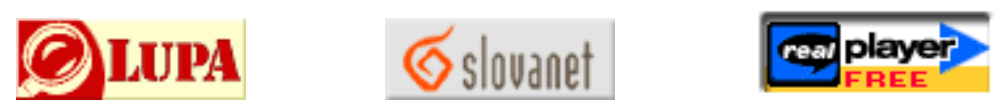

Obrázok 8 Microbutton

Býva zvykom, že umiestnenie bannera práve tohto formátu na stránku, je odplatou za bezplatné využívanie rôznych služieb (počítadlá, freehosting, zaradenie do zoznamov, resp. zvýraznenie v zozname...). Prevádzkovatel' vyslovene podmieňuje užívanie služby práve umiestnením microbuttonu na stránke zákazníka. Na Slovensku systém dobrovol’nej propagácie využívajú napr. servery Naj.sk, Zoznam.sk, Superzoznam.sk a iné .

\section{Interstitial}

Interstitial je vel'koplošná reklama, ktorá sa zobrazí v celom okne obrazovky ešte pred načítaním obsahu. Doba zobrazenia sa pohybuje od 5 až do 30 sekúnd. Býva dobrým zvykom túto reklamnú oblast' filtrovat' na základe detekcie IP adresy užívatel'a $(1 \times$ deň / IP, alebo $3 \times$ týždeň / IP). Zvyčajne sa dodáva ako obrázok, či animácia, ktorý sa umiestni uprostred 
stránky na dohodnutom farebnom pozadí. Dôležitá je čo najmenšia vel'kost', pretože inak výrazne rastie pravdepodobnost', že užívatel' stratí trpezlivost' a stlačí "SKIP>>" , teda nepočká na načítanie oblasti a tým je reklama nefunkčná.

\section{J. Superstitial}

Superstitial je dnes asi najprepracovanejšou formou reklamy. Ide o snímok vytvorený najčastejšie technológiou Macromedia Flash, ktorý sa zobrazuje v samostatnom okne. Dôležitý je však princíp, na ktorom sa superstitial zobrazuje - označuje sa ako "polite delivery“ (slušné zobrazenie). Znamená to, že stránka sa načíta bez toho, aby si ktokol'vek čokol'vek všimol. Ako náhle však dôjde k úplnému načítaniu reklamy (načítavaná na pozadí), reklama sa zobrazí v popredí s možnost’ou jej zrušenia známym „X“, známeho z prostredia OS Windows.
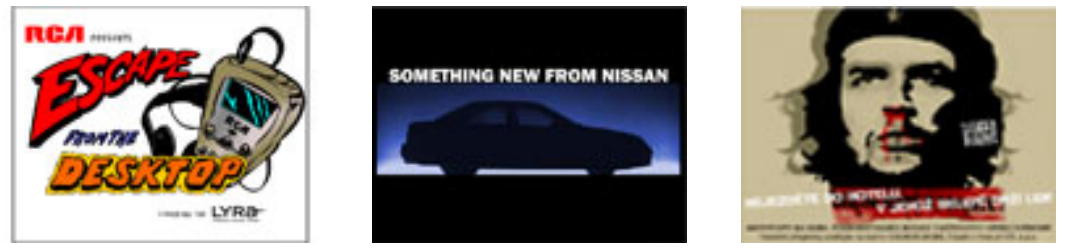

Obrázok 9 Superstitial

\section{K. Stick-ad}

Velmi efektná forma bannera, podstatou ktorej je udržanie stabilnej pozície reklamnej grafiky aj pri rolovaní dokumentu. Tento efekt je možné docielit’ niektorým zo skriptovacích jazykov, ako napr. Java Script, alebo VBasic Script. Väcšinou sa stretávame so situovaním bannera v pravom spodnom rohu obrazovky.

\section{Roll over}

Tento banner pripomína Splash, ale kým sa doplnková informácia pri splashi vysunie na začiatku, roll over čaká, kým naň ukáže kurzor myši - odtial' aj jeho pomenovanie - ked' kurzor ukazuje na odkaz bez toho, aby sa naňho kliklo, je v polohe OVER.

\section{Layer}

Layer patrí k najagresívnejším reklamným bannerom vôbec. Ide o grafiku o vel'kosti cca $100 \times 100$ pixelov, ktorá sa "vznáša" nad načítaným dokumentom. Často ide o logo "odrážajúce sa" od okrajov obrazovky, prípadne symbol, ktorý preletí z jednej strany na druhú, kde opät' zmizne. V snahe zabránit' prílišnému obt’ažovaniu návštevníkov býva tento reklamná plocha filtrovaná čím sa zabráni jej opätovnému načítaniu počas vopred dohodnutého časového obdobia (zvyčajne 24 h).

Z pohl'adu technológií použitých pre vytvorenie reklamných bannerov a z pohl'adu výsledného spracovania banneru je možné rozdelit’ bannerovú reklamu na:

- statickú

- animovanú

- interaktívnu

Statickú bannerovú rekalmu predstavujú v podstate fixné obrázky (typické vo formáte GIF alebo JPEG), ktoré obsahujú reklamný odkaz. Patrí medzi historicky najstaršiu bannerovú reklamu na internete. Hlavnou výhodou statických bannerov je jednoduchost' ich výroby. Všeobecne platí čím menší rozmer, tým univerzálnejšie použitie. Statické reklamné 
bannery podporujú všetky základné systémy na internete, obzvlášt' tzv. plný banner (468x60 pixelov) patrí medzi najrozšírenejšie reklamné bannery vôbec.

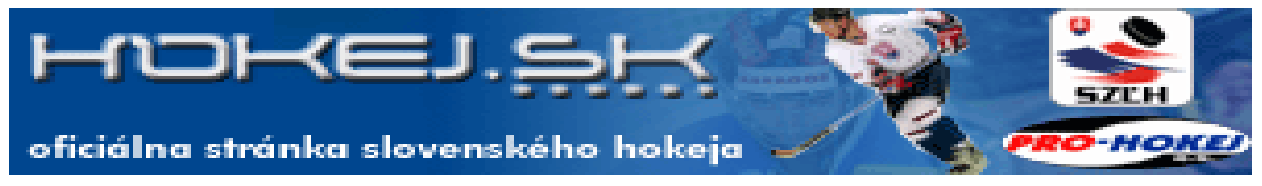

Obrázok 10 Statický full banner

Animovaná bannerová reklama je realizovaná obvykle vo formáte GIF 98 a na rozdiel od statickej bannerovej reklamy dovol'uje zaradit' viac obrázkov za sebou. Tie je možné v predne stanovených časových intervaloch striedat' a vyvolat' tak dojem jednoduchej animácie. Hlavnou výhodou animovaných bannerov je možnost' zobrazit' pohyb, teda prevádzat' zmenu obsahu plochy banneru. To samo o sebe vedie k ovel'a väčšiemu upútaniu pozornosti, než je tomu v prípade statických reklamných bannerov.

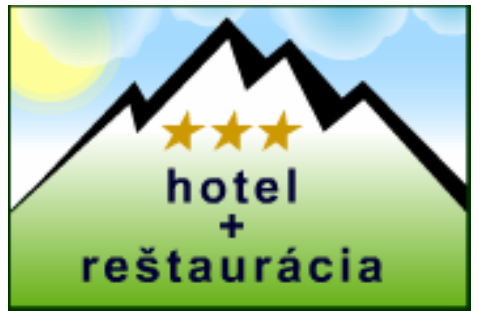

1. plocha animácie
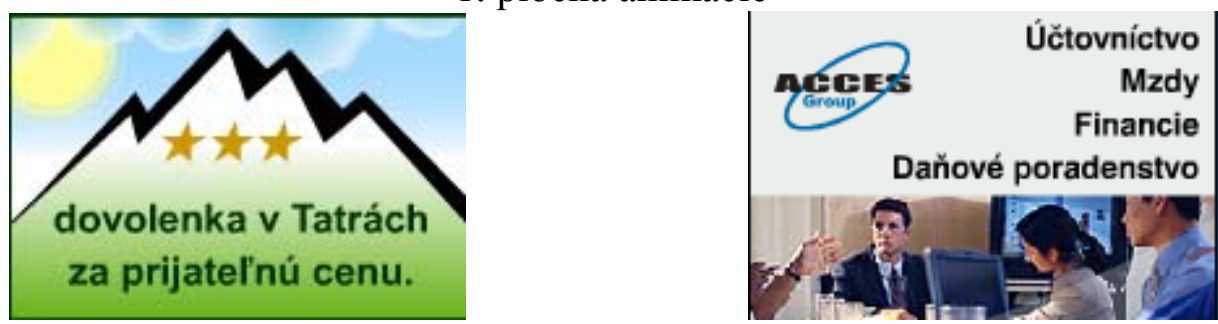

2. plocha animácie
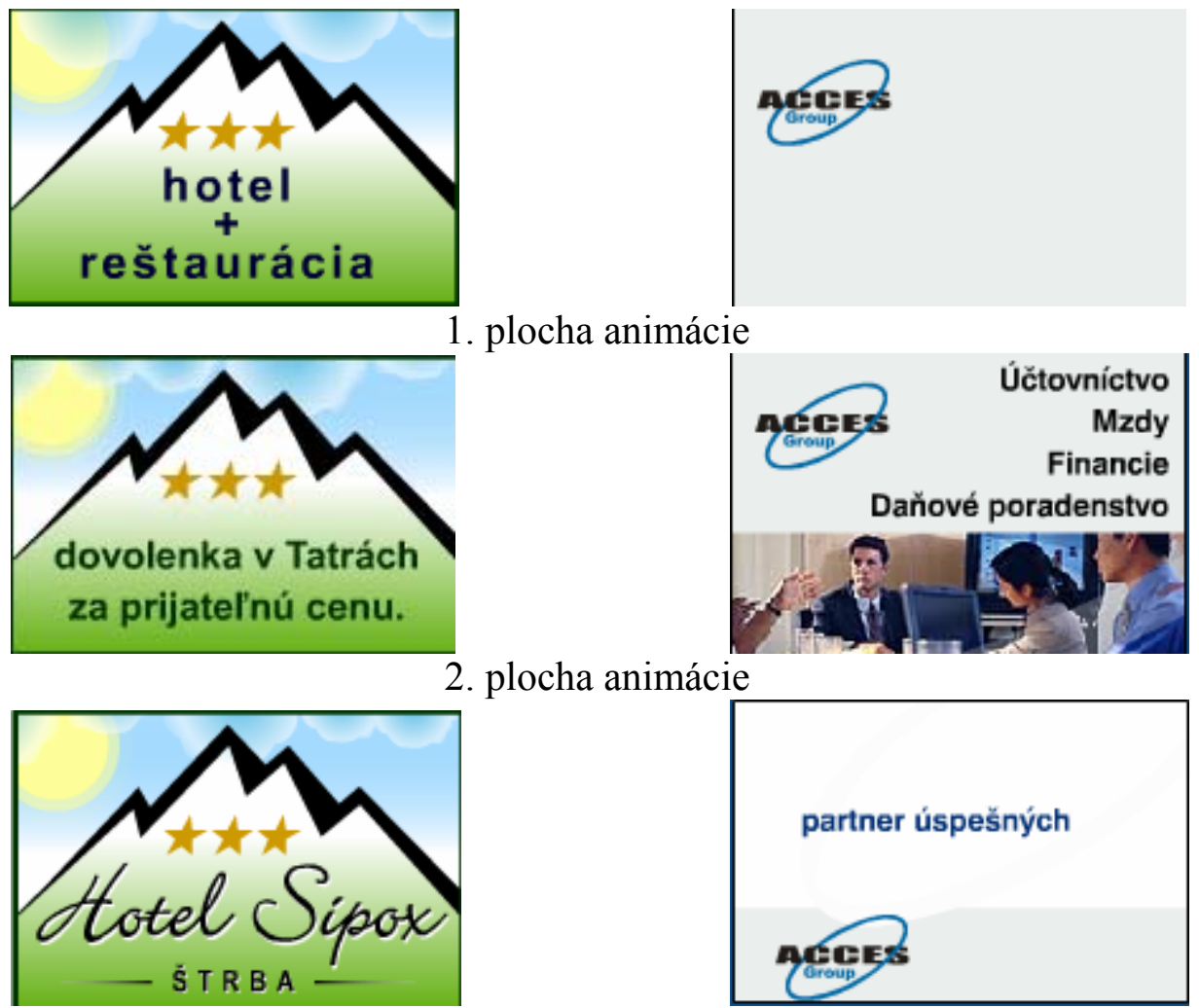

3. plocha animácie

Obrázok 11 Animovaný banner

Základnou nevýhodou animovaných bannerov je ich vel'kost'. Zatial' čo statické bannery zaberujú v priemere $3-8 \mathrm{kB}$, animované bannery obsahujú väčšie množstvo obrázkov a logicky majú aj niekol'ko násobnú vel'kost'. Obvykle sa udáva, že maximálna vel'kost' animovaného banneru by nemala dosahovat' $20 \mathrm{kB}$. V praxi sa dajú akceptovat' aj bannery o vel'kosti $25 \mathrm{kB}$. Načítanie takého banneru však už dlhšie a zvlášt' u pomalých pripojeniach do internetu sa často stáva, že používatel' prejde na inú stránku skôr, než sa celá reklamná oblast' načíta a začne animovane zobrazovat' celý reklamný odkaz.

Nevýhodou je tiež náročný proces tvorby animovaného banneru. Designer bannera pri tvorbe obvykle používa dva programy: grafický editor a špecializovaný softvér. S jeho 
pomocou riadi obrázky bannera do sekvencie za sebou a nastavuje dobu omeškania medzi jednotlivými animáciami.

Interaktívne reklamné bannery patria medzi najnovšie prvky internetového reklamného trhu. Ciel'om interaktívnych bannerov je upútat' pozornost' používatel'ov a ponúknut' viac funkcií, ako iba jednoduché kliknutie, s ciel'om získat' väčšie množstvo informácií $\mathrm{k}$ danej téme.

Podskupinu interaktívnych reklamných bannerov tvoria HTML bannery, ktoré ponúkajú a zobrazujú viac informácií. Napríklad predstavujú jednoduchý vstupný formulár smerovaný na d'alší spravidla externý serveru, alebo ak je reklama určená na predaj mobilných telefónov, reklamný banner obsahuje drop-down menu, v ktorom si používatel' vyberie typ telefónu, o ktorý má záujem. Po výbere sa automaticky dostáva na konkrétnu stránku s ponukou na vybraný telefón. Týmto spôsobom jedna reklamná oblast' odkazuje na vel'ké množstvo d'alších stránok, čo nie je možné pri statických a animovaných banneroch.

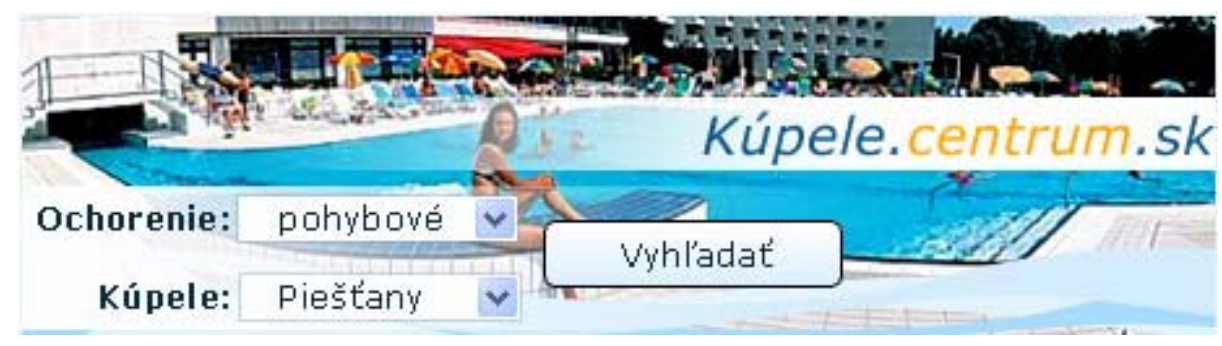

Obrázok 12 HTML banner

Jednou z foriem interaktívnych bannerov sú Rich Media bannery. Ide o elementy obsahujúce časti HTML kódov doplnených o aktívne prvky. Tými môžu byt' Java, JavaScript, InterVU, RealAudio,VRLM, Macromedia Flash a iné. Napríklad pomocou technológie InterVU je možné v časti bannera zobrazit' krátku (obvykle 3-5 sekundovú) videosekvenciu, ktorá sa pravidelne opakuje. Videosekvencia je načítaná až po plnom zobrazení banneru, čiže používatel' nemusí čakat' kým sa banner celý načíta a spustí sa animácia.

Ani interaktívne reklamné bannery nie sú úplne bez chýb. Najväščím nedostatkom je ich malá podpora zo stany reklamných systémov a ich väčšia vel'kost' $\mathrm{v}$ porovnaní $\mathrm{s}$ klasickými statickými reklamnými bannermi.

\section{Záver}

Bannerová reklama ako taká, sa $\mathrm{z}$ internetového priestoru nevytratí, ba naopak. Z jej charakteru vyplýva jedinečná vlastnost' a to možnost' nevtieravou a neagresívnou formou, pomocou jediného odkazu sa dostat' priamo k potenciálnemu obchodníkovi, resp. zákazníkovi

\section{Literatúra}

[1] MADLEŇÁK, R.: Elektronický obchod, Žilinská univerzita v Žiline, Žilina, 2004, 160 str., ISBN 80-8070-192-X

[2] VACULÍK, J.: Marketing v prostredí internetu, In: Zborník príspevkov z medzinárodnej vedeckej konferencie KIT 2003, 26.-28. november 2003, Liptovský Mikuláš, Vojenská akadémia, 2003, ISBN 80-968711-4-5, s. 7-11.

[3] ČOREJOVÁ, T.: K problematike cenových modelov v elektronických komunikačných službách. In: marketing a obchod 2004. Rok európskej integrácie. Zborník z medzinárodnej vedeckej konferencie, Zvolen 2004, ISBN 80-89100-20-1 
[4] ČOREJOVÁ, T., MAJERČÁKOVÁ, M.: K vybraným problémom postavenia zákazníka na info-komunikačných trhoch, In: Globalizácia a jej sociálno-ekonomické dôsledky '04 : zborník príspevkov, 6.-7. október 2004, Rajecké Teplice, Žilinská univerzita v Žiline, 2004, ISBN 80-8070-310-8., s. 70-74.

[5] HLAVENKA, J.: Internetový marketing. Computer Press, Praha, 2001. ISBN 80-7226498-2

[6] STUCHLÍK, P.; DVOŘÁČEK, M.: Marketing na Internetu. Grada Publishing, Praha, 2000. ISBN 80-7169-957-8

\section{Grantová podpora}

1/1265/04 VEGA MŠ SR a SAV - Výskum siet’ových procesov v rámci odvetvových zoskupení firiem SR

1/2591/05 VEGA MŠ SR a SAV - Vplyv výberu efektívnej stratégie na udržiavanie konkurencie schopnosti podniku v rámci liberalizácie poštových trhov 